Article

\title{
Co-Immobilization of Ketoreductase and Glucose Dehydrogenase
}

\author{
Tatiana Petrovičová ${ }^{1}$, Kristína Markošová ${ }^{1}$, Zuzana Hegyi ${ }^{1}$, Ioulia Smonou ${ }^{2}$ (D), \\ Michal Rosenberg ${ }^{1}$ and Martin Rebroš ${ }^{1, *}$ \\ 1 Institute of Biotechnology, Faculty of Chemical and Food Technology, Slovak University of Technology, \\ Radlinského 9,812 37 Bratislava, Slovakia; tatiana.petrovicova@stuba.sk (T.P.); xmarkosova@stuba.sk (K.M.); \\ zuzana.hegyi@stuba.sk (Z.H.); michal.rosenberg@stuba.sk (M.R.) \\ 2 Department of Chemistry, University of Crete, Heraklion 71003, Greece; smonou@uoc.gr \\ * Correspondence: martin.rebros@stuba.sk; Tel.: +421-2-59-325-480
}

Received: 29 March 2018; Accepted: 18 April 2018; Published: 20 April 2018

\begin{abstract}
A two-enzyme system composed of immobilized ketoreductase (Hansenula polymorpha) and glucose dehydrogenase (Bacillus megaterium) was developed for the asymmetric reduction of keto esters to optically active hydroxy esters via immobilization in polyvinyl alcohol (PVA) gel particles. The concentration of enzymes was optimized, and the final particles were used 18 times in a row in a batch mode to achieve minimal loss of activity and complete conversion of the model substrate, $\beta$-ketoester ethyl-2-methylacetoacetate. Excellent stability was also achieved using new storage conditions of PVA particles, with $80 \%$ of activity being retained after almost 10 months.
\end{abstract}

Keywords: ketoreductase; co-immobilization; PVA gel

\section{Introduction}

Ketoreductases (KREDs) are powerful tools for the asymmetric reduction of ketone substrates to optically active alcohols, which are useful chiral building blocks in chemical and pharmaceutical industries [1]. Numerous potentially interesting substrates were tested, including aryl $\gamma, \delta$-unsaturated- $\beta$-ketoesters [2], various substituted $\beta$-ketoesters [3-6], diaryl ketones [7], and bicyclic ketones [8]. All KREDs require a reduced cofactor $\mathrm{NAD}(\mathrm{P}) \mathrm{H}$, which increases the cost of their application. Therefore, cofactor recycling systems were applied to overcome this problem [9]. One of the well-established systems consists of glucose dehydrogenase (GDH)/glucose.

Despite the many advantages of and recent successes in biocatalysis, the use of enzymes is often hampered by a lack of long-term operational stability due to low-substrate solubility in the aqueous reaction system, poor enzyme stability in commonly-used organic solvents, and difficulties in recovering and reusing the enzyme. Enzyme immobilization provides an attractive approach to overcoming these drawbacks [1]; however, the immobilization of KREDs remains challenging and only a few examples have been reported. For example, one system used nonporous glass as a support for the KRED and was used in a continuous gas-phase reactor [10]. Another system used covalent binding of KRED on resin EC-HFA, which was applied in both batch mode and flow reactor mode [1]. KRED and GDH were also separately immobilized on aldehyde-activated agarose and used in a flow reactor to perform stereoselective ketone reduction [11]. Combined cross-linked enzyme aggregates (combi-CLEAs) of KRED and GDH were used for repeated conversions of ethyl 4-chloro-3-oxobutanoate (COBE). The system retained 70\% of its activity after 10 cycles in aqueous system probably because of relatively weaker bond between enzyme molecules [12].

LentiKats ${ }^{\circledR}$ is an entrapment technology that has been applied for the immobilization of whole cells and enzymes [13-21]. Its lens-shaped capsules are made of polyvinyl alcohol gel which offers 
several advantages such as low matrix costs, inexpensive and simple gel preparation, low diffusion limits, etc. [13]; however, the co-immobilization of redox enzymes linked with cofactor regeneration have not been studied to date. Scale-up process of immobilization into PVA gel is also possible and was reviewed recently [22].

This article reports the optimization and application of co-entrapped KRED and GDH in a PVA gel.

\section{Results and Discussion}

\subsection{KRED and GDH Expression and Purification}

The KRED gene from H. polymorpha was first sequenced and cloned by Hanson et al. and the enzyme was used to prepare (S)-2-chloro-1-(3-chloro-4-fluorophenyl)-ethanol with $81 \%$ yield and excellent optical purity $>99 \%$ ee [23]. GDH (EC. 1.1.1.47) from B. megaterium was chosen for effective NADPH regeneration.

Enzymes were expressed in E. coli BL21(DE3) with a combined lac and T7 promoter. The presence of enzymes (Supplementary Material Figure S1, (a) KRED: 32 kDa, (b) GDH: 35 kDa) was checked by SDS-PAGE. Enzymes were further purified, concentrated, and desalted, which was verified by protein electrophoresis (Supplementary Material Figure S2).

The activity of purified enzymes was determined spectrophotometrically by cofactor utilization separately for each enzyme. The initial specific activity of GDH was $45.7 \mathrm{U} \cdot \mathrm{mg}^{-1}$, which was 3.5-fold higher than the initial specific activity of KRED $\left(13.06 \mathrm{U} \cdot \mathrm{mg}^{-1}\right)$. Based on the $\mathrm{pH}$ and temperature profiles of KRED and GDH (Figure 1), $\mathrm{pH} 6.5$ and $37^{\circ} \mathrm{C}$ were chosen as the conditions for all experiments. According to spectrophotometric measurements of enzyme temperature profiles, the optimal temperatures were $25-35^{\circ} \mathrm{C}$; however, in combined cascade reaction with both enzymes, $37^{\circ} \mathrm{C}$ was observed as the optimum for product formation. For the same type of KRED, pH 7 and $30^{\circ} \mathrm{C}$ were used as the optimal conditions [23], while $\mathrm{pH}$ 6.9-7 and $32-37^{\circ} \mathrm{C}$ were used for commercial KREDs $[2,3,8]$.

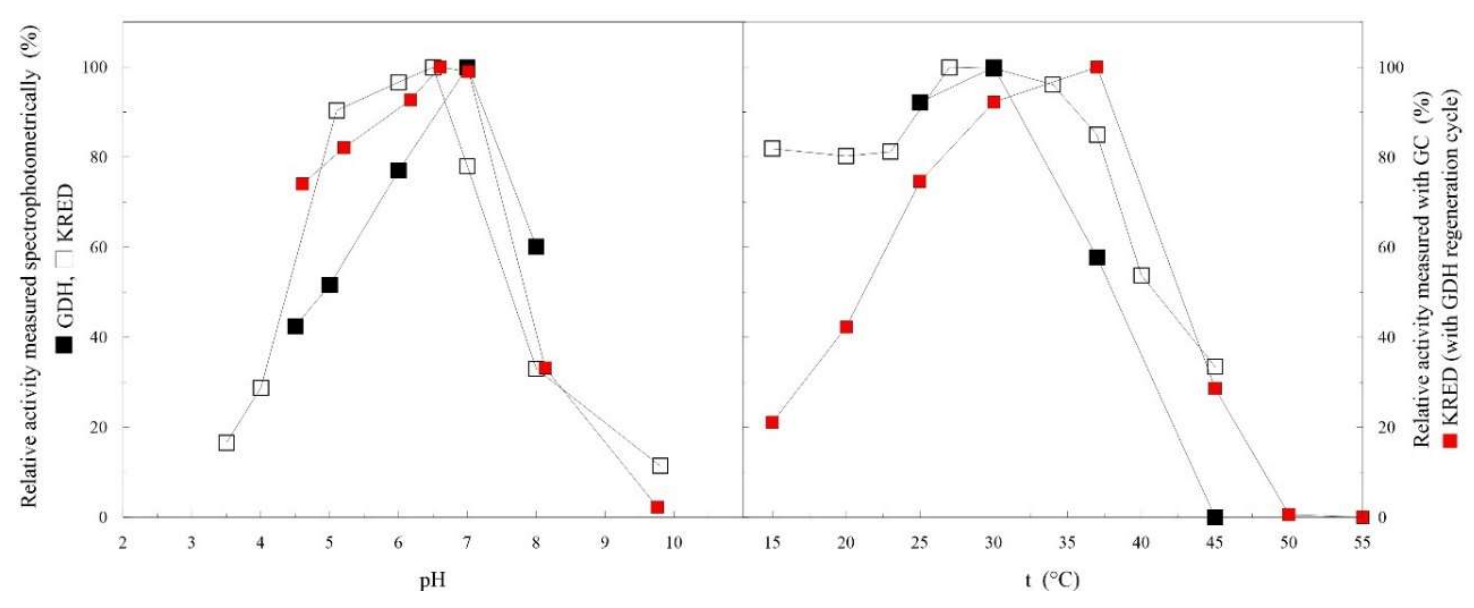

Figure 1. $\mathrm{pH}$ and temperature profile of KRED and GDH.

\subsection{Free-Enzyme Biotransformations}

Biotransformations were performed to verify the activity of purified KRED in combination with NADPH regeneration with GDH (Section 3.6). Ethyl-2-methylacetoacetate, which is an $\alpha$-alkyl- $\beta$-keto ester, was selected as a model substrate for these purposes. This group of substrates are used in relatively low concentrations $(25-50 \mathrm{mM})$ due to their low solubility in water and their potential ability to inhibit enzymes [3].

Free enzymes were used at different ratios for the complete conversion of the substrate (Supplementary Material, Figures S3 and S4). According to the results summarized in Table 1, a five-fold 
higher concentration of KRED increased the initial activity approximately five and half times and total conversion of the substrate was achieved within $90 \mathrm{~min}$. In contrast, a four-fold increase in the GDH concentration had no significant effect on initial activity. As expected, KRED was the rate-limiting enzyme and GDH was added in excess in biotransformations. GDH was previously used at concentrations equal to [3] or three-quarters lower than KRED [23], which is similar to the experiments reported above. One study reported the effect of GDH concentration on reaction rate in the kinetic resolution of 11-oxo-5,6,7,8,9,10-hexahydro-6,9-methanobenzocyclooctene and an increasing rate was only observed until $0.15 \mathrm{~g} \cdot \mathrm{dm}^{-3}$, while the KRED concentration was $0.2 \mathrm{~g} \cdot \mathrm{dm}^{-3}$ [8]. This represents a KRED:GDH ratio of 1.33:1. In general, to overcome the limitation of NADPH access in the reaction, GDH should always be in excess and the enzyme ratio should be optimized.

Table 1. Biotransformations with free enzymes.

\begin{tabular}{ccccc}
\hline KRED:GDH & C KRED $\left(\mu \mathrm{g} \cdot \mathrm{mL}^{-\mathbf{1}}\right)$ & $\mathbf{C ~ G D H}\left(\boldsymbol{\mu g} \cdot \mathbf{m L}^{-\mathbf{1}}\right)$ & Initial Activity (U) & Final Conversion $(\%)$ \\
\hline $1: 1.7$ & 9.21 & 15.79 & 0.27 & 84 \\
$5: 1.7$ & 46.04 & 15.79 & 1.51 & $>99$ \\
$5: 6.9$ & 46.04 & 63.16 & 1.85 & $>99$ \\
\hline
\end{tabular}

\subsection{Optimization of Co-Immobilization}

Various factors of LentiKats ${ }^{\circledR}$ need to be verified as the co-immobilization of two or more enzymes using this technology has not been described to date. As for the free enzymes, the most important factor is determining the optimal concentration and ratio of both enzymes to achieve total substrate conversion in a reasonable time. Five different ratios and concentrations of KRED and GDH were used for co-immobilizations (Table 2). Based on the free-enzyme experiments described above, KRED was added in excess as it is rate limiting enzyme.

The graph in Figure 2 displays the dependence of initial specific activity on the concentrations of enzymes entrapped in particles. A four-fold lower amount of KRED and a constant concentration of GDH led to a three-fold decrease in activity while only a $50 \%$ conversion rate was achieved. Half of the amount of KRED had no influence on initial specific activity. The concentration of GDH in batch four was limiting and caused a significant decrease in activity, while a two-fold higher amount made no additional improvements. Therefore, $0.19 \mathrm{mg} \cdot \mathrm{g}^{-1} \mathrm{LKs}$ of GDH was optimum. The major impact of KRED concentration within particles was proven in the free-enzyme reactions. To prevent the possible inactivation of KRED during co-immobilization and the repetitive use of particles for all further experiments, a KRED:GDH weight ratio of 25:1 was applied (batch number 1, Table 2). The ratio depends on the enzyme activities; for example, in previously reported immobilized KRED and GDH cascades, the optimal KRED:GDH ratio was 1:25 [11], which is opposite to the results reported here. Furthermore, the concentrations of KRED (Table 2) used were very low in comparison with the $100 \mathrm{~g} \cdot \mathrm{dm}^{-3}$ of KRED used in the immobilization on EC-HFA resin [1].

Table 2. Concentration of enzymes loaded into particles.

\begin{tabular}{|c|c|c|c|c|c|}
\hline Batch Nr. & KRED:GDH & $\begin{array}{c}\text { C KRED } \\
\left(\mathrm{mg} \mathrm{g}^{-1}{ }_{\text {LKs }}\right)\end{array}$ & $\begin{array}{c}\mathrm{c}_{\mathrm{GDH}} \\
\left(\mathrm{mg} \mathrm{g}^{-1}{ }_{\text {LKs }}\right)\end{array}$ & $\begin{array}{c}\text { Initial Specific } \\
\text { Activity }\left(\mathrm{U} \mathrm{g}^{-1} \text { LKs }\right)\end{array}$ & $\begin{array}{c}\text { Conversion }{ }^{a} \\
(\%)\end{array}$ \\
\hline 1 & $25: 1$ & 4.84 & 0.19 & 3.63 & $>99$ \\
\hline 2 & $12.5: 1$ & 2.42 & 0.19 & 3.62 & 92 \\
\hline 3 & $6.25: 1$ & 1.21 & 0.19 & 1.29 & 50 \\
\hline 4 & $12.5: 0.5$ & 2.42 & 0.1 & 2.74 & 92 \\
\hline 5 & $12.5: 2$ & 2.42 & 0.39 & 3.69 & 95 \\
\hline
\end{tabular}

LKs-LentiKats ${ }^{\circledR}$ particles. ${ }^{\text {a }}$ after $90 \mathrm{~min}$. 


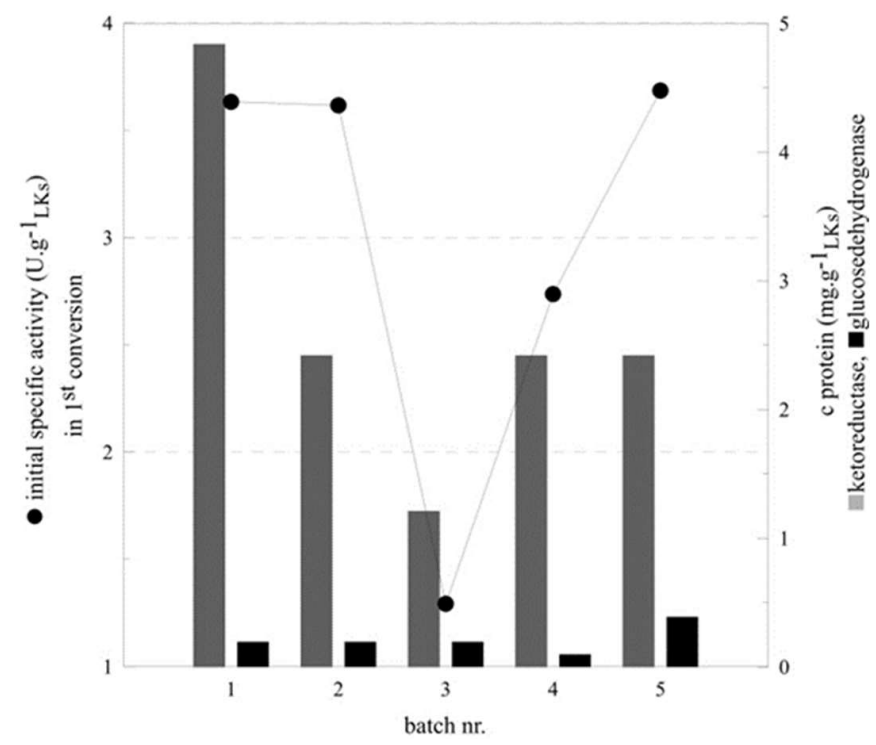

Figure 2. Influence of KRED and GDH concentrations in co-immobilization on the initial specific activity in biotransformations.

\subsection{Repeated Biotransformations}

To verify the stability of selected co-immobilized KRED and GDH (Table 2, batch number 1), particles were used for 18 repeated batch bioconversions in nonstop mode. Three parallel reactions were stopped at different stages of the conversion $(50,60$, and $90 \mathrm{~min}$ ) to see how the presence of the product could influence the level of bioconversion and the initial specific activity (Figure 3). The non-constant trend of activity during repeated bioconversions can be caused by different residual reaction components after each washing of particles. There were observed similar effect in work with PVA particles before [19]. The activity of the 90-min reaction dropped at the same speed as the others despite particles being exposed to the highest product concentrations, therefore inhibition was excluded. The level of total conversion was still $>95 \%$, which is an advantage for product separation and downstream processing.

Conversely, the 50-min reaction had the highest activity decline (36\%), which may have been caused by the substrate remaining in the particles after each round. The total level of conversion decreased faster than in the other reactions, which also signifies possible inhibition by the accumulated substrate.

The 60-min biotransformations achieved the most consistent results. The overall activity decline was only $16 \%$ after 18 biotransformations, while the total conversion reached $90 \%$ for all rounds. Termination of the biotransformation at the exact moment of substrate utilization seemed to be optimal for stability of the co-immobilized enzymes' activity.

Despite the least activity decrease being achieved with the 60-min reaction, a better method would be to let the reaction run to the total conversion as product inhibition was not observed and the subsequent product separation is easier without any residual substrate.

In comparison, only a few KRED immobilizations have been described; for example, covalent binding of KRED on EC-HFA resin with a self-isopropanol regeneration cycle showed no activity decrease during 10 repetitions [1], and covalent binding of KRED on aldehyde-activated agarose together with immobilized GDH in a flow reactor for 15 days also showed no activity decrease [11].

Co-immobilized enzymes demonstrated possible reusability with $80 \%$ retained activity and $>95 \%$ conversion, which is an enormous advantage and yield increasing mainly in biotransformations with small concentrations of inhibiting ketone substrates (25-100 mM). Enantiomeric ratio of chiral products was not changed after co-immobilization of enzymes (Supplementary Material Figures S11 and S12). Complete time graphs of the bioconversions are provided in the Supplementary Material, Figures S8-S10. 


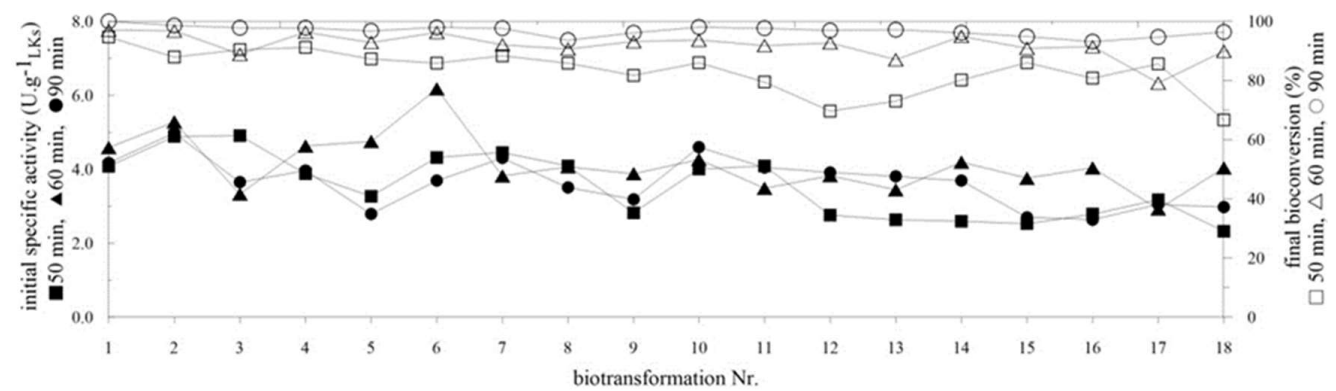

Figure 3. Initial specific activity and final bioconversion in repeated biotransformations of three parallel reactions of co-immobilized KRED and GDH.

\subsection{Storage of Particles}

The storage of immobilized enzymes is one of the crucial parameters in applied immobilized biocatalysis. Samples from batch number 1 (Table 2) were stored at $4{ }^{\circ} \mathrm{C}$ in $0.1 \mathrm{M}$ potassium phosphate buffer ( $\mathrm{pH}$ 6.5) or at $-80^{\circ} \mathrm{C}$ without any buffer or solvent. After each biotransformation, particles were washed twice with buffer and stored. Storage at $4{ }^{\circ} \mathrm{C}$ caused a significant decrease in relative activity after $90 \mathrm{~h}$ (Figure 4) and is therefore not suitable for these co-immobilized enzymes. Storage at $4{ }^{\circ} \mathrm{C}$ was chosen based on the previously reported application for immobilized invertase [19]. The particles retained $78 \%$ of activity after eight months. Complete time graphs of the bioconversions are provided in the Supplementary Material, Figures S5-S7).

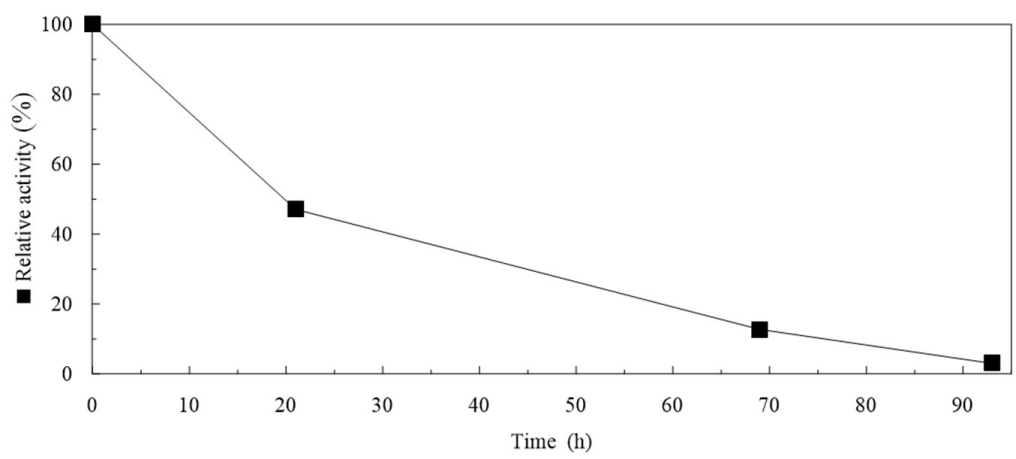

Figure 4. Relative activity of co-immobilized KRED and GDH during storage at $4{ }^{\circ} \mathrm{C}$.

The particles stored at $-80{ }^{\circ} \mathrm{C}$ surprisingly retained $87 \%$ of their relative activity after nine-and-a-half months (Figure 5). This was the first-time the storage conditions of PVA particles had been reported and it showed a huge improvement compared with storage at $4{ }^{\circ} \mathrm{C}$ where particles lost their entire activity after four days. Moreover, the properties of the PVA particles remained unchanged.

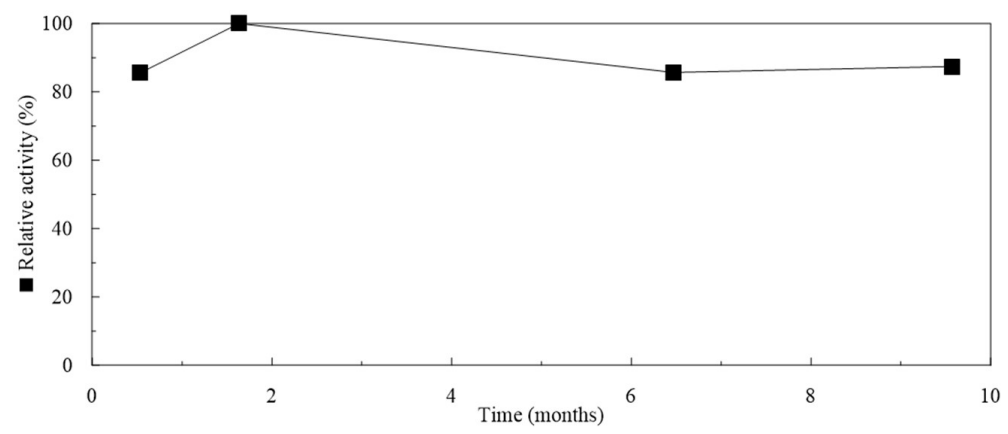

Figure 5. Relative activity of co-immobilized KRED and GDH during storage at $-80^{\circ} \mathrm{C}$. 


\section{Materials and Methods}

\subsection{Chemicals and Media}

Kanamycin was purchased from Gibco ${ }^{\circledR}$ (Life Technologies, Glasgow, UK), ethyl-2-methylacetoacetate was purchased from Sigma-Aldrich (St. Louis, MO, USA) and $\mathrm{NADP}^{+}$and NADPH were purchased from Prozomix (Haltwhistle, UK). All other chemicals were of analytical grade and were commercially available. Luria-Bertani (LB) medium contained 1\% $(w / v)$ $\mathrm{NaCl}, 1 \%(w / v)$ tryptone, and $0.5 \%(w / v)$ yeast extract, and plates additionally contained $2 \%(w / v)$ agar. Kanamycin was used at a concentration of $30 \mu \mathrm{g} \cdot \mathrm{mL}^{-1}$.

\subsection{Cloning}

Codon-optimized genes encoding KRED from Hansenula polymorpha [23] and GDH from Bacillus megaterium were obtained from Generay Biotech Co., Ltd. (Shanghai, China). Genes were inserted into a pET28b vector system, and these plasmids were transformed into Escherichia coli BL21(DE3) cells.

\subsection{Preparation and Purification of KRED and GDH}

An inoculum of E. coli BL21(DE3) expressing KRED or GDH was prepared from a single colony. Glass tubes containing $3 \mathrm{~mL}$ of LB medium were incubated overnight at $37^{\circ} \mathrm{C}$ and $200 \mathrm{rpm}$. After approximately $12 \mathrm{~h}$, a $500 \mathrm{~mL}$ flask containing $100 \mathrm{~mL}$ of LB medium was inoculated with $1 \%(v / v)$ inoculation culture and cultivated at $37^{\circ} \mathrm{C}$ and $200 \mathrm{rpm}$. Isopropyl $\beta$-D-thiogalactopyranosid was added at a final concentration $0.5 \mathrm{mM}$ when the cell density at OD600 reached 0.5-0.6.

After cultivation at $30^{\circ} \mathrm{C}$ for $3 \mathrm{~h}$, the induced cells were harvested by centrifugation $(7197 \times g$, $15 \mathrm{~min}, 4^{\circ} \mathrm{C}$ ). The sediment was subsequently resuspended in $20 \mathrm{~mL}$ of $0.1 \mathrm{M}$ potassium phosphate buffer (KRED: $\mathrm{pH}$ 6.5; GDH: $\mathrm{pH}$ 7). The cell suspension was disrupted in a continual cell disruptor (CF Range, Constant Systems Ltd., Daventry, UK) in two cycles at $4{ }^{\circ} \mathrm{C}$ and $20 \mathrm{kPSI}$. After disruption, $70 \mu \mathrm{L}$ of protease inhibitor (Complete EDTA-free, Roche, Berlin, Germany) per $20 \mathrm{~mL}$ of cell lysate was added. The cell debris was removed by centrifugation $\left(7197 \times g, 30 \mathrm{~min}, 4{ }^{\circ} \mathrm{C}\right)$.

The cell extract was filtered (Filtropur S, $0.2 \mu \mathrm{m}$; Sarstedt, Germany) and loaded onto $5 \mathrm{~mL}$ HisTrapTM FF columns (GE Healthcare, Chicago, IL, USA) equilibrated with binding buffer (pH 5.8, $300 \mathrm{mM}$ sodium phosphate, $300 \mathrm{mM} \mathrm{NaCl}$ and $10 \mathrm{mM}$ imidazole). Enzymes were eluted with $80 \%$ (KRED) or 75\% (GDH) elution buffer (pH 7.4, $300 \mathrm{mM}$ sodium phosphate, $300 \mathrm{mM} \mathrm{NaCl}$, and $500 \mathrm{mM}$ imidazole) using an ÄKTA purifier system (GE Healthcare, Chicago, IL, USA). The presence of expressed proteins in eluted fractions was determined by sodium dodecyl sulfate polyacrylamide gel electrophoresis (SDS-PAGE) (Mini PROTEAN ${ }^{\circledR}$ Tetra Cell, Bio-Rad, Hercules, CA, USA). Fractions showing a band of the expected size (GDH: 35 kDa; KRED: $32 \mathrm{kDa}$ ) were pooled, concentrated either 180 (KRED) or 40 times $(\mathrm{GDH})$ and desalted using $3 \times 14.5 \mathrm{~mL}$ of $0.1 \mathrm{M}$ potassium phosphate buffer (pH 6.5) using an Amicon ${ }^{\circledR}$ Ultra centrifugation membrane (15 mL, 30 kDa; Merck, Kenilworth, NJ, USA).

\subsection{Enzyme Assays}

KRED assays $(1 \mathrm{~mL})$ contained $0.1 \mathrm{M}$ potassium phosphate buffer ( $\mathrm{pH}$ 6.5), $35 \mathrm{mM}$ ethyl 2-methylacetoacetate and $16.53 \mu \mathrm{g} \cdot \mathrm{mL}^{-1}$ of purified enzyme. The reaction was started with $0.5 \mathrm{mM}$ NADPH and its decrease was measured spectrophotometrically at $340 \mathrm{~nm}$. GDH assays (1 mL) contained $0.1 \mathrm{M}$ potassium phosphate buffer ( $\mathrm{pH} 7), 100 \mathrm{mM}$ glucose, and $3.72 \mu \mathrm{g} \cdot \mathrm{mL}^{-1}$ of purified enzyme. The reaction was started with $0.5 \mathrm{mM}$ NADP+. One unit of an enzyme was defined as the amount of KRED catalyzing the oxidation of $1 \mu \mathrm{mol} \mathrm{NADPH} / \mathrm{min}$ or the amount of GDH catalyzing the reduction of $1 \mu \mathrm{mol} \mathrm{NADP}^{+} / \mathrm{min}$ at a $\mathrm{pH}$ of $6.5(\mathrm{KRED})$ or $7(\mathrm{GDH})$ and $25^{\circ} \mathrm{C}$. Experiments were duplicated.

The concentrations of purified enzymes were measured spectrophotometrically at $280 \mathrm{~nm}$ using an Eppendorf $\mu$ Cuvette ${ }^{\circledR}$ G1.0 (Eppendorf, Hauppauge, NY, USA). The initial specific activity was expressed in units/mg of protein used in the reaction. 


\subsection{Co-Immobilization}

LentiKats ${ }^{\circledR}$ technology was used for co-immobilization. The PVA gel was composed of polyvinyl alcohol (PVA, $10 \% w / v)$, polyethylene glycol $(6 \% w / v)$, and water. The amount of water varied according to the concentration of the added enzyme (Table 2). This mixture was heated at $90{ }^{\circ} \mathrm{C}$ for $30 \mathrm{~min}$ before being cooled at $40{ }^{\circ} \mathrm{C}$ under continuous stirring. Enzymes were added to the mixture in a dropwise manner and, after approximately $5 \mathrm{~min}$, the particles were prepared by dripping onto a polyethylene plate using a syringe. The PVA drops were subsequently dried in an air flow cabinet at $35-40{ }^{\circ} \mathrm{C}$ for $45 \mathrm{~min}$ and hardened in $0.1 \mathrm{M}$ sodium sulfate. The prepared particles were washed with a sterile $0.1 \mathrm{M}$ potassium phosphate buffer ( $\mathrm{pH}$ 6.5) and used directly for biocatalysis.

\subsection{Biotransformation}

Ethyl 2-methylacetoacetate, was used as a $\beta$-keto ester substrate for the KRED biotransformations. The GDH regeneration system (Figure 6) was used to regenerate NADPH. The reaction mixture contained 0.1 M potassium phosphate buffer ( $\mathrm{pH}$ 6.5), $35 \mathrm{mM}$ ethyl 2-methylacetoacetate, $100 \mathrm{mM}$ glucose, $1 \mathrm{mM} \mathrm{NADP}^{+}$, and free or $20 \%(w / v)$ co-immobilized enzyme. Free enzymes were used in different concentrations and ratios as reported in Table 1 . The amount of buffer added depended on the volume of enzyme used. In repeated batch biotransformations, the particles were washed twice in $0.1 \mathrm{M}$ potassium phosphate buffer ( $\mathrm{pH}$ 6.5) after each biotransformation. Reactions were carried out in Eppendorf tubes in a total volume of $1 \mathrm{~mL}$ at $37^{\circ} \mathrm{C}$ with shaking at 550 (free enzymes) or $700 \mathrm{rpm}$ (co-immobilized enzymes). Experiments were duplicated.

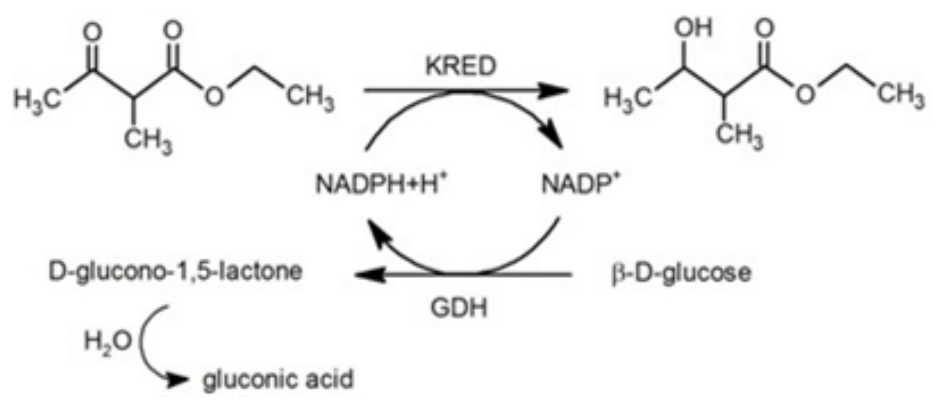

Figure 6. Reduction of ethyl 2-methylacetoacetate to ethyl 3-hydroxy-2-methylbutanoate by NADPH-dependent KRED combined with cofactor regeneration system using GDH.

\subsection{Analytics}

During the biotransformations, $10 \mu \mathrm{L}$ of sample was taken at regular intervals and $0.5 \mathrm{~mL}$ of ethyl acetate was added to the extract substrate and product. After vortexing, the sample was centrifuged $(13,300 \times g, 1 \mathrm{~min})$ to facilitate phase separation. The organic phase was transferred to a glass vial for analysis. The bioconversion of keto ester to hydroxy ester was monitored by gas chromatography-flame ionization detector (GC-FID) (Agilent 6890N, Santa Clara, CA, USA) with a DB-5 capillary column (Agilent $\mathrm{J} \& \mathrm{~W}, 30 \mathrm{~m} \times 0.25 \mathrm{~mm} \times 0.25 \mu \mathrm{m}$ ) and $\mathrm{H}_{2}$ as the carrier gas with a flow of $1 \mathrm{~mL} \cdot \mathrm{min}^{-1}$. The volume of injection was $1 \mu \mathrm{L}$ with split $50: 1$. The oven temperature was initially $90^{\circ} \mathrm{C}$ for $5.5 \mathrm{~min}$, but increased to $280^{\circ} \mathrm{C}$ with a gradient of $30^{\circ} \mathrm{C} / \mathrm{min}$ and was held for $3 \mathrm{~min}$.

The percentage conversion was evaluated as the peak area of alcohol product/(peak area of ketone substrate + peak area of alcohol product $) \times 100$. One unit of KRED was the amount of enzyme that catalyzed the production of $1 \mu \mathrm{mol} \cdot \mathrm{min}^{-1}$ of hydroxy ester (Figure 6). The middle volume of the reaction mixture was included in the calculation of co-immobilized KRED activity. The initial specific activity of free (or co-immobilized) KRED was defined as $\mu \mathrm{mol}$ of hydroxy ester (Figure 6) produced/min by $1 \mathrm{mg}$ of KRED (or $1 \mathrm{~g}$ of particles). 
The activity decline during repeated biotransformations with co-immobilized KRED and GDH was evaluated as the difference between the average first five and last five activities and was expressed as a percentage.

\section{Conclusions}

KRED and GDH were successfully produced, purified and co-immobilized using PVA entrapment technology and applied in a cascade reaction with NADPH regeneration. This immobilization method was used for the first time for a two-enzyme cascade. The ratio of enzymes entrapped in particles was optimized, and the best option (KRED:GDH $=25: 1$ ) was employed in 18 repeated batch conversions of ethyl-2-methylacetoacetate. Particles retained approximately $80 \%$ of their activity, which is the highest stability of co-immobilized KRED reported to date. Furthermore, the storage of co-immobilized redox enzymes was found to be effective when particles were stored without any buffer or solvent at $-80^{\circ} \mathrm{C}$. Particles lost $20 \%$ of their initial activity after almost 10 months of storage and their mechanical properties remained unchanged. This storage technique may also be applied to other immobilized unstable oxidoreductases.

Supplementary Materials: The following are available online at http:/ /www.mdpi.com/2073-4344/8/4/168/s1. Figure S1 (a) expression of KRED (32 kDa); column 1-molecular standard, 2-start of induction, 3-after 2h, 4-after 3h, 5-cell extract (b) expression of GDH (35 kDa); 1-molecular standard, 2-start of induction, 3-after 1h, 4-after $2 \mathrm{~h}, 5$-after $3 \mathrm{~h}, 6$ - cell extract. Conditions of induction for both KRED and GDH: $30^{\circ} \mathrm{C}$, 0.5 mM IPTG, Figure S2 Purification of (a) KRED (1-molecular standard, 2-3-flow through, 4-unspecific proteins eluted with $25 \%$ elution buffer, 5 -KRED eluted with $80 \%$ elution buffer) and (b) GDH (1-molecular standard, 2-3-flow through, 4-unspecific proteins eluted with 20\% elution buffer, 5-6-GDH eluted with $75 \%$ elution buffer). Figure S3 Product conversion in biotransformations with free ketoreductase (KRED) and glucosedehydrogenase (GDH) with three different ratios (KRED:GDH) of enzymes: nr. 1-1:1.7; nr. 2-5:1.7; nr. 3-5:6.9. Figure S4 Influence of KRED:GDH ratio and enzyme concentration on initial activity in biotransformation with free enzymes. Figure S5 Product conversion in biotransformations with co-immobilzed enzymes nr. 1 during six biotransformations with 12 -h storage at $4{ }^{\circ} \mathrm{C}$ in potassium phosphate buffer $(0.1 \mathrm{M} ; \mathrm{pH}=6.5)$ after 3 rd, 4 th and 5th batch. Figure S6 Product conversion in biotransformations with co-immobilzed enzymes nr. 2 during five biotransformations with 12 -h storage at $4{ }^{\circ} \mathrm{C}$ in potassium phosphate buffer $(0.1 \mathrm{M} ; \mathrm{pH}=6.5)$ after $3 \mathrm{rd}$ and 4th batch. Figure S7 Product conversion in biotransformations with co-immobilzed enzymes nr. 5 during five biotransformations with 12-h storage at $4{ }^{\circ} \mathrm{C}$ in potassium phosphate buffer $(0.1 \mathrm{M} ; \mathrm{pH}=6.5)$ after 3 rd and 4 th batch. Figure S8 Product conversion in 18 batches of 50-min reactions. Figure S9 Product conversion in 18 batches of 60-min reactions. Figure S10 Product conversion in 18 batches of 90-min reactions. Figure S11 Chromatogram of hydroxy ester product after biotransformation with free enzymes. Figure S12 Chromatogram of hydroxy ester product after biotransformation with co-immobilized enzymes. Figure S13 Bioconversions after $45 \mathrm{~h}$ and relative activity of free and co-immobilized enzymes with different substrate concentrations.

Acknowledgments: This work was done during implementation of the project Establishment of Competence center for research and development in the field of molecular medicine, ITMS code 26240220071, supported by the Research and Development Operational Program funded by ERDF.

Author Contributions: Tatiana Petrovičová and Kristína Markošová performed immobilized and free enzyme experiments; Martin Rebroš and Zuzana Hegyi performed the cloning experiments; Tatiana Petrovičová, Martin Rebroš and Ioulia Smonou analyzed the data, wrote the manuscript; Michal Rosenberg and Martin Rebroš contributed funding of the research, immobilization set up.

Conflicts of Interest: The authors declare no conflict of interest.

\section{References}

1. Li, H.M.; Moncecchi, J.; Truppo, M.D. Development of an immobilized ketoreductase for enzymatic (r)-1-(3,5-bis(trifluoromethyl)phenyl)ethanol production. Organ. Process Res. Dev. 2015, 19, 695-700. [CrossRef]

2. Dai, Z.; Guillemette, K.; Green, T.K. Stereoselective synthesis of aryl $\gamma, \delta$-unsaturated $\beta$-hydroxyesters by ketoreductases. J. Mol. Catal. B Enzym. 2013, 97, 264-269. [CrossRef]

3. Kalaitzakis, D.; David Rozzell, J.; Kambourakis, S.; Smonou, I. Highly stereoselective reductions of $\alpha$-alkyl-1,3-diketones and $\alpha$-alkyl- $\beta$-keto esters catalyzed by isolated nadph-dependent ketoreductases. Org. Lett. 2005, 7, 4799-4801. [CrossRef] [PubMed] 
4. Guo, Z.; Chen, Y.; Goswami, A.; Hanson, R.L.; Patel, R.N. Synthesis of ethyl and t-butyl $(3 \mathrm{r}, 5 \mathrm{~s})$-dihydroxy-6-benzyloxy hexanoates via diastereo- and enantioselective microbial reduction. Tetrahedron Asymmetry 2006, 17, 1589-1602. [CrossRef]

5. Zhu, D.; Mukherjee, C.; Rozzell, J.D.; Kambourakis, S.; Hua, L. A recombinant ketoreductase tool-box. Assessing the substrate selectivity and stereoselectivity toward the reduction of $\beta$-ketoesters. Tetrahedron 2006, 62, 901-905. [CrossRef]

6. Kaluzna, I.A.; David Rozzell, J.; Kambourakis, S. Ketoreductases: Stereoselective catalysts for the facile synthesis of chiral alcohols. Tetrahedron Asymmetry 2005, 16, 3682-3689. [CrossRef]

7. Li, H.; Zhu, D.; Hua, L.; Biehl, E.R. Enantioselective reduction of diaryl ketones catalyzed by a carbonyl reductase from sporobolomyces salmonicolor and its mutant enzymes. Adv. Synth. Catal. 2009, 351, 583-588. [CrossRef]

8. Truppo, M.D.; Kim, J.; Brower, M.; Madin, A.; Sturr, M.G.; Moore, J.C. A novel resolution of a pharmaceutically important bridged bicyclic ketone intermediate via selective enzymatic reduction with a commercially available ketoreductase. J. Mol. Catal. B Enzym. 2006, 38, 158-162. [CrossRef]

9. Milner, S.E.; Maguire, A.R. Recent trends in whole cell and isolated enzymes in enantioselective synthesis. Arkivoc 2012, 2012, 321-382.

10. Nagayama, K.; Spiess, A.C.; Büchs, J. Gas phase enantioselective reduction catalyzed by immobilized ketoreductase: Effects of water activity and reaction temperature. Biochem. Eng. J. 2010, 52, 301-303. [CrossRef]

11. Dall'Oglio, F.; Contente, M.L.; Conti, P.; Molinari, F.; Monfredi, D.; Pinto, A.; Romano, D.; Ubiali, D.; Tamborini, L.; Serra, I. Flow-based stereoselective reduction of ketones using an immobilized ketoreductase/glucose dehydrogenase mixed bed system. Catal. Commun. 2017, 93, 29-32. [CrossRef]

12. Ning, C.; Su, E.; Tian, Y.; Wei, D. Combined cross-linked enzyme aggregates (combi-cleas) for efficient integration of a ketoreductase and a cofactor regeneration system. J. Biotechnol. 2014, 184, 7-10. [CrossRef] [PubMed]

13. Rebroš, M.; Rosenberg, M.; Mlichová, Z.; Krištofíková, L.; Paluch, M. A simple entrapment of glucoamylase into lentikats ${ }^{2}$ as an efficient catalyst for maltodextrin hydrolysis. Enzym. Microb. Technol. 2006, 39, 800-804. [CrossRef]

14. Rebroš, M.; Rosenberg, M.; Stloukal, R.; Krištofíková, L. High efficiency ethanol fermentation by entrapment of zymomonas mobilis into lentikats®. Lett. Appl. Microbiol. 2005, 41, 412-416. [CrossRef] [PubMed]

15. Rosenberg, M.; Rebroš, M.; Krištofíková, L.; Malátová, K. High temperature lactic acid production by bacillus coagulans immobilized in lentikats. Biotechnol. Lett. 2005, 27, 1943-1947. [CrossRef] [PubMed]

16. Dolejš, I.; Krasňan, V.; Stloukal, R.; Rosenberg, M.; Rebroš, M. Butanol production by immobilised clostridium acetobutylicum in repeated batch, fed-batch, and continuous modes of fermentation. Bioresour. Technol. 2014, 169, 723-730. [CrossRef] [PubMed]

17. Rebroš, M.; Dolejš, I.; Stloukal, R.; Rosenberg, M. Butyric acid production with clostridium tyrobutyricum immobilised to pva gel. Process Biochem. 2015, 51, 704-708. [CrossRef]

18. Cerreti, M.; Markošová, K.; Esti, M.; Rosenberg, M.; Rebroš, M. Immobilisation of pectinases into pva gel for fruit juice application. Int. J. Food Sci. Technol. 2017, 52, 531-539. [CrossRef]

19. Rebroš, M.; Rosenberg, M.; Mlichová, Z.; Krištofíková, L. Hydrolysis of sucrose by invertase entrapped in polyvinyl alcohol hydrogel capsules. Food Chem. 2007, 102, 784-787. [CrossRef]

20. Grosová, Z.; Rosenberg, M.; Rebroš, M.; Šipocz, M.; Sedláčková, B. Entrapment of $\beta$-galactosidase in polyvinylalcohol hydrogel. Biotechnol. Lett. 2008, 30, 763-767. [CrossRef] [PubMed]

21. Grosová, Z.; Rosenberg, M.; Gdovin, M.; Sláviková, L.; Rebroš, M. Production of d-galactose using $\beta$-galactosidase and saccharomyces cerevisiae entrapped in poly(vinylalcohol) hydrogel. Food Chem. 2009, 116, 96-100. [CrossRef]

22. Krasnan, V.; Stloukal, R.; Rosenberg, M.; Rebros, M. Immobilization of cells and enzymes to lentikats(r). Appl. Microbiol. Biotechnol. 2016, 100, 2535-2553. [CrossRef] [PubMed]

23. Hanson, R.L.; Goldberg, S.; Goswami, A.; Tully, T.P.; Patel, R.N. Purification and cloning of a ketoreductase used for the preparation of chiral alcohols. Adv. Synth. Catal. 2005, 347, 1073-1080. [CrossRef]

(C) 2018 by the authors. Licensee MDPI, Basel, Switzerland. This article is an open access article distributed under the terms and conditions of the Creative Commons Attribution (CC BY) license (http:/ / creativecommons.org/licenses/by/4.0/). 